Document downloaded from:

http://hdl.handle.net/10251/49119

This paper must be cited as:

Guiñon Pina, V.; Igual Muñoz, AN.; García Antón, J. (2011). Influence of pH on the electrochemical behaviour of a duplex stainless steel in highly concentrated $\mathrm{LiBr}$ solutions. Corrosion Science. 53(2):575-581. doi:10.1016/j.corsci.2010.09.066.

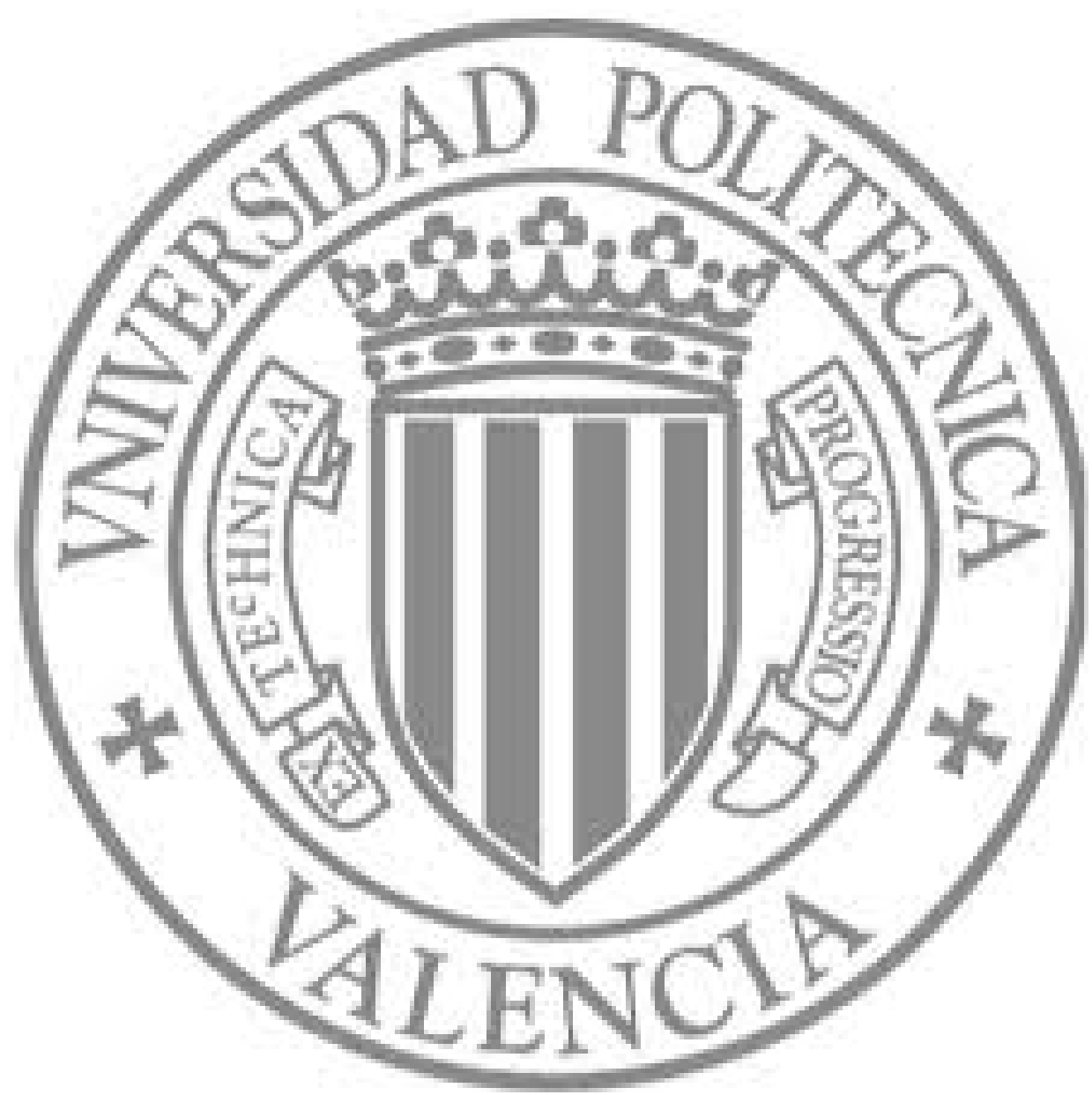

The final publication is available at

http://dx.doi.org/10.1016/j.corsci.2010.09.066

Copyright Elsevier 


\title{
INFLUENCE OF PH ON THE ELECTROCHEMICAL BEHAVIOR OF A DUPLEX STAINLESS STEEL IN HIGHLY CONCENTRATED LiBr SOLUTIONS
}

\author{
V. Guiñón-Pina; A. Igual-Muñoz; J. García-Antón* \\ Ingeniería Electroquímica y Corrosión (IEC), Departamento de Ingeniería Química y \\ Nuclear. ETSI Industriales. Universidad Politécnica de Valencia. E-46022, Valencia. \\ Spain.
}

Phone. 34-96-387 76 30, Fax. 34-96-387 76 39, e-mail. jgarciaa@iqn.upv.es

\begin{abstract}
The objective is to study the influence of $\mathrm{pH}$ on the corrosion and passive behavior of duplex stainless steels (DSS) using potentiodynamic measurements, potentiostatic tests and electrochemical impedance spectroscopy (EIS).

DSS are spontaneously passive in heavy brine $\mathrm{LiBr}$ solutions. Under potentiostatic conditions at applied anodic potentials within the passive domain an equivalent circuit with two time constants is the most suitable model to describe the corrosion mechanism in the interface electrolyte // passive film // metal. $\mathrm{pH}$ modifies the electrochemical properties of the passivity of the alloy in a $992 \mathrm{~g} / \mathrm{L} \mathrm{LiBr}$ solution reducing its resistance with the applied potential.
\end{abstract}

Keywords: A. Duplex Stainless Steel; B. EIS; B. Polarization; B. Potentiostatic; C. Passivity. 


\section{INTRODUCTION}

Aqueous solutions containing high concentrations of lithium bromide ( $\mathrm{LiBr})$ are used as absorbent solutions in absorption heating and refrigeration systems that use natural gas or steam as energy sources $[1,2]$. Although $\mathrm{LiBr}$ possesses favorable thermophysical properties, high heat of hydration, high solubility of solid phases, good thermal stability and appropriate viscosity, it can cause serious corrosion problems on metallic components in refrigeration systems and heat exchangers in absorption plants $[3-5]$.

In general, stainless steels possess the ability to form passive films. Passivity is a crucial factor in determining the capability of metals to resist corrosion. Investigation of the electrochemistry of a passivated metal can reveal not only the structure and composition, but also the corrosion behavior of the film [6]. The corrosion resistance of a passive metal is often determined by its susceptibility to local breakdown and pit initiation. It has been demonstrated $[7,8]$ that the growth of corrosion pits occurs in two consecutive stages characterized by a metastable growth in the early period, followed by stable growth.

Duplex stainless steels (DSS) are iron-based alloys that possess a two phase microstructure: austenite and delta ferrite in approximately similar percentages. DSS combine the attractive properties of austenitic and ferritic stainless steels: high tensile strength and fatigue strength, good toughness even at low temperatures, adequate formability and weldability and excellent resistance to stress corrosion cracking, pitting and general corrosion $[9,10]$. They find increasing use as an alternative to austenitic stainless steels, particularly where aggressive anions such as chloride or bromide are present in high concentrations. 
The advantage of using DSS in media that contain halides, such as chloride or bromide, resides in the content of delta ferrite, which promotes combined effects due to electrochemical and mechanical factors. Owing to two different elastic limits, lower in austenite than in ferrite, plastic deformation under external load concentrates on the austenite, while ferrite acts as an anode protecting the austenite, which acts as the cathode [10].

Selective dissolution in DSS is expected to occur due to the difference in chemical composition of the constituent phases. Yau and Streicher [11] indicated that selective corrosion of the ferritic $(\alpha)$ phase occurred in Fe-Cr-10\%Ni DSS in reducing acid. Similar observations have been reported by Symniotis with a DSS (SAF 2205) and Laitinen et al. in different DSS [12, 13]. However, selective dissolution of the austenitic $(\gamma)$ phase has also been reported by Sridhar and Kolts [14]. Recently, the first step of DSS corrosion in $\mathrm{LiBr}$ has been observed in-situ by means of potentiodynamic and galvanodynamic techniques in a minicell with a Confocal Laser Scanning Microscope (CLSM) [15]. In DSS each phase can exhibit a different electrochemical potential, which may facilitate the occurrence of galvanic corrosion.

There are numerous studies of the properties of passive films in aqueous solutions. Some authors have investigated the effect of $\mathrm{pH}$ in different materials, like $\mathrm{Al}, \mathrm{Fe}$ and different stainless steels in sodium sulphate, sodium chloride or diverse buffer solutions; all authors have found that an increase in $\mathrm{pH}$ enhances passivity and repassivity, and a thickening of the passive film is observed in general [16-19]. However, studies on the influence of $\mathrm{pH}$ on duplex stainless steels in bromide solutions have not been found.

The aim of this work is to study the effect of $\mathrm{pH}$ on the electrochemical behavior of DSS, and to explain the mechanism of corrosion and passivation processes taking 
place at the electrode/electrolyte interface in lithium bromide solutions. The effect of $\mathrm{pH}$ has been studied in heavy brine $\mathrm{LiBr}$ solutions as a possible corrosion inhibitor needed to reduce the corrosion rates of metallic materials in these halide media, to reduce the aggressiveness of the environment towards metals by small additions, in this case, $\mathrm{LiOH}$ or $\mathrm{HBr}$. In previous papers the effect of different inhibitors in $\mathrm{LiBr}$ solutions has been studied [20]. For these investigations, different electrochemical techniques, open circuit measurements (OCP), polarization techniques and electrochemical impedance spectroscopy (EIS) were used.

\section{Experimental details}

2.1. Electrodes and solution.

The working electrodes were made from commercial duplex stainless steel rods, (EN 1.4462), $8 \mathrm{~mm}$ in diameter. The chemical composition (wt $\%$ ) is $4.84 \% \mathrm{Ni}$, $22.336 \% \mathrm{Cr}, 2.686 \% \mathrm{Mo}, 1.598 \% \mathrm{Mn}, 0.354 \% \mathrm{Si}, 0.134 \% \mathrm{Cu}, 0.030 \% \mathrm{C}, 67.794 \%$ $\mathrm{Fe}, 0.008 \% \mathrm{Ti}$ and $0.1760 \% \mathrm{~N}$. In a previous study the content of ferrite and austenite of the DSS was determined (45\% and 55\% respectively), and the optical micrographs of the same DSS was presented there [21]. For the electrochemical tests, the specimens were mounted in Teflon leaving a working area of $0.5 \mathrm{~cm}^{2}$ in contact with the solution. Before each experiment, the working electrode was mechanically polished using successive grade grinding papers up to 4000 grit, rinsed with distilled water, dried with air and then transferred to the test solution.

All measurements were performed in aqueous $992 \mathrm{~g} / \mathrm{L}$ LiBr solutions, prepared from 98 wt.\% LiBr, from PANREAC. The $\mathrm{pH}$ was adjusted by adding $\mathrm{LiOH}$ or $\mathrm{HBr}$ at 2, 4, 6, 8, 10 and 12. Before the experiments nitrogen was bubbled through the solution for 15 minutes in order to remove the dissolved oxygen from the solution; during the 
electrochemical measurements $\mathrm{N}_{2}$ atmosphere was kept by introducing the gas over the liquid surface during the whole test. All the experiments were repeated at least three times. The reference electrode was a $\mathrm{Ag} / \mathrm{AgCl}$ electrode in $3 \mathrm{M} \mathrm{KCl}$, and a platinum wire was used as the counter electrode. All potentials were referred to the $\mathrm{Ag} / \mathrm{AgCl} 3 \mathrm{M}$ $\mathrm{KCl}$ electrode (205 mV versus SHE).

\subsection{Electrochemical equipment and measurements}

The experiments were carried out using an electrochemical three-electrode vertical cell. The solution temperature was held at $25{ }^{\circ} \mathrm{C}$ during all the experiments. All measurements were carried out using a potentiostat Solartron 1287 and a frequency response analyzer Solartron SI 1250 including a personal computer with a GPIB. Experiments were controlled with ZPlot and CorrWare software and fitting was performed with ZView and CorrView software respectively.

Two different electrochemical tests have been conducted in $\mathrm{LiBr}$ aqueous solutions: cyclic potentiodynamic curves, performed to assess corrosion resistance by recording anodic and cathodic currents, and electrochemical impedance spectroscopy (EIS) testing, performed to describe the metallic interface.

Open circuit potential was measured for one hour at the beginning of the tests. The OCP values were obtained, according to ASTM G5 [22], from the average value of the last $300 \mathrm{~s}$ of the open circuit potential measurement.

Cyclic potentiodynamic curves were carried out according to a modification of the ASTM G 61 standard [23]; after one hour of immersion at open circuit potential using a scan rate of $0.5 \mathrm{mV} / \mathrm{s}$ started from $-1 \mathrm{~V}_{\mathrm{Ag} / \mathrm{AgCl}}$ and moved in the anodic direction; the potential scan was reversed when the current density reached a value of $10 \mathrm{~mA} / \mathrm{cm}^{2}$. Corrosion current density $\left(\mathrm{i}_{\text {corr }}\right)$, corrosion potential $\left(\mathrm{E}_{\text {corr }}\right)$, pitting potential $\left(\mathrm{E}_{\mathrm{p}}\right)$ at a 
current density of $100 \mu \mathrm{A} / \mathrm{cm}^{2}$, passivation current density ( $i_{p}$ ) repassivation potentials $\left(\mathrm{E}_{\mathrm{rp}}\right)$ and repassivation current density $\left(\mathrm{i}_{\mathrm{rp}}\right)$ were obtained from the polarization curves. $\mathrm{i}_{\text {corr }}$ were obtained by the extrapolation of the cathodic and anodic slopes between 50 and $100 \mathrm{mV}$ away from $\mathrm{E}_{\text {corr }}$. The most precise determination of the corrosion current density values is by the Tafel extrapolation when both the anodic and cathodic branches show linearity. However, it is also possible to make an accurate evaluation of the corrosion current densities if one of the branches of the polarization curves displays a sufficiently long linear tendency around the corrosion potential [24-27]. In fact, two rules of thumb should be applied when using Tafel extrapolation. First, at least one of the branches of the polarization curve should exhibit Tafel behavior (i.e., linear on semilogarithmic scale) over about one decade of current density. Second, the extrapolation should start at least $50-100 \mathrm{mV}$ away from $\mathrm{E}_{\text {corr. }}$ These two rules improve the accuracy of manual extrapolation [28].

The potentiostatic test was recorded at $-0.2 \mathrm{~V}_{\mathrm{Ag} / \mathrm{AgCl}}$ during one hour. Passivation current density at the steady state $\left(\mathrm{i}_{\mathrm{pss}}\right)$ was determined from them.

EIS were recorded at different potentials: OCP and $-0.2 \mathrm{~V}_{\mathrm{Ag} / \mathrm{AgCl}}$. The selected potentials corresponded to the passive domain of the alloy. Measurements have been performed starting from $10 \mathrm{mHz}$ up to $10^{4} \mathrm{~Hz}$, at 10 data cycles/decade, $10 \mathrm{mV}$ ac amplitude.

Impedance at the OCP was carried out after 1 hour immersion. The impedance measurements under potentiostatic conditions were carried out after 30 minutes immersion at $\mathrm{OCP}, 10$ minutes of electrochemical cleaning at $-1 \mathrm{~V}_{\mathrm{Ag} / \mathrm{AgCl}}$ and one hour at the selected potential, $-0.2 \mathrm{~V}_{\mathrm{Ag} / \mathrm{AgCl}}$. 


\section{Results and discussion}

\subsection{Open circuit potential}

The open circuit potential (OCP) values are summarized in Table 1. All the values of each parameter in Table 1 are the mean values of three repetitions and they are presented with their corresponding standard deviation. All the values lay between -216 and $-140 \mathrm{mV}_{\mathrm{Ag} / \mathrm{AgCl}}$, which corresponds to the passive region of the electrode in the $\mathrm{LiBr}$ solutions of $\mathrm{pH}$ between 4 and 12. The OCP value obtained in $\mathrm{pH} 2$ is close to the breakdown potential value as it can seen in Table 1, while between 4 and 10 differences in OCP values are negligible. The evolution of the open circuit potential versus time in LiBr solutions at $\mathrm{pH}$ 2, 4, 6, 8, 10 and 12 is shown in Figure 1; in all the experiments open circuit potential increases with time independently of the $\mathrm{pH}$, indicating a spontaneous passivation of the surface due to the development of an oxide film. At $\mathrm{pH}$ 12, the OCP value is similar to $\mathrm{pH} 2$. Due to the fact that the passive film is composed of chromium and iron oxides, but mainly chromium oxides [29], it can be observed from the Pourbaix diagram of chromium in $992 \mathrm{~g} / \mathrm{L} \mathrm{LiBr}$ solution at $25^{\circ} \mathrm{C}$ [30] that at slightly acidic, neutral and basic pHs, chromium shows corrosion resistance by passivity due to the presence of protective oxide of the form $\mathrm{Cr}_{2} \mathrm{O}_{3}$.

\subsection{Cyclic potentiodynamic curves}

Figure 2 shows the polarization curves of DSS in $992 \mathrm{~g} / \mathrm{L} \mathrm{LiBr}$ solutions. The electrochemical parameters calculated from the curves are listed in Table 1. DSS do not passivate at $\mathrm{pH} 2$; it presents the highest corrosion potential $\left(-272 \mathrm{mV}_{\mathrm{Ag} / \mathrm{AgCl}}\right)$ and the highest corrosion current density $\left(1.8 \mu \mathrm{A} / \mathrm{cm}^{2}\right)$. According to Dieter Landolt [31], it is established that one material is nobler when the corrosion potential increases, so that, in the LiBr solution with $\mathrm{pH}$ 2, DSS presents the worst corrosion behavior in $992 \mathrm{~g} / 1 \mathrm{LiBr}$ 
at $25^{\circ} \mathrm{C}$. DSS passes directly from the cathodic to the active state in the $\mathrm{pH} 2$ solution. The highest cathodic current density in all the cathodic branch is obtained in the LiBr pH 2 solution.

In the other $\mathrm{LiBr}$ solutions, four different zones can be distinguished in the polarization curves. The first region, the cathodic domain, comprises a potential range between -1 and $-0.6 \mathrm{~V}_{\mathrm{Ag} / \mathrm{AgCl}}$. For the acidic pHs, Figure 2 (a), the cathodic current density decreases with $\mathrm{pH}$, the highest being at $\mathrm{pH} 2$, favouring the cathodic reaction of hydrogen evolution.

The second region, the active passive transition, is observed between -0.6 and $0.4 \mathrm{~V}_{\mathrm{Ag} / \mathrm{AgCl}}$. In $\mathrm{LiBr}$ solutions with $\mathrm{pHs}$ between 4 and 12 , the corrosion potential is around $-0.5 \mathrm{~V}_{\mathrm{Ag} / \mathrm{AgCl}}$. The corrosion rate of DSS increases when $\mathrm{pH}$ decreases and $\mathrm{pH} 12$ presents the lowest corrosion current density (Table 1).

The third region is the passive domain, and it is observed at all pHs above 2; this region is wider at the highest $\mathrm{pH}$. Above $\mathrm{pH} 4$, DSS is well passivated, it presents low passive current densities (between 5 and $8 \mu \mathrm{A} / \mathrm{cm}^{2}$ ). The passivation current densities, $\mathrm{i}_{\mathrm{p}}$, are very similar in all media, but it slightly decreases when $\mathrm{pH}$ increases. L. Freire et al [32] relate the decrease in passive current density from $\mathrm{pH} 13$ to 9 in AISI 316 in $\mathrm{NaOH}+\mathrm{KOH}$ due to an enrichment in Cr oxides that improves the stability of the films, resulting in a lower $i_{p}$. Pitting potential represents the potential limit above which pitting begins. $\mathrm{pH}$ do not influence the $\mathrm{E}_{\mathrm{p}}$ between 6 and 8, while at $\mathrm{pH} 12 \mathrm{DSS}$ presents the highest $\mathrm{E}_{\mathrm{p}}\left(24 \mathrm{mV} \mathrm{V}_{\mathrm{Ag} / \mathrm{AgCl}}\right)$. Otherwise some authors have concluded that the influence of $\mathrm{pH}$ on the pitting potential of different stainless steels have no significant effects [33]; from our results it is shown that for basic $\mathrm{pHs}$ (Figure $2 b$ ), $\mathrm{E}_{\mathrm{p}}$ increases with $\mathrm{pH} . \mathrm{E}_{\mathrm{p}}$ shifts to more positive values with an increase in $\mathrm{pH}$ of the solution and it obeys the equation: 


$$
\mathrm{E}_{\mathrm{p}}=\mathrm{a}+\mathrm{b} \mathrm{pH}
$$

The intercept $a$ and the slope $b$ are found to be $-305 \mathrm{mV}$ and $27.37 \mathrm{mV} / \mathrm{dec}$ respectively. This indicates that the stability of the passive film towards pitting corrosion increases as the $\mathrm{pH}$ values increase. At the lowest $\mathrm{pHs}$, the increase in the instability in the passive film could be due to the acceleration of the cathodic reaction owing to high concentration of hydrogen ions. Ramana et al [34] have found the same tendency of $\mathrm{E}_{\mathrm{p}}$ with $\mathrm{pH}$ for $316 \mathrm{~L}$ stainless steel in chlorine media in a $\mathrm{pH}$ range between 1.23 and 5.

Figure 3 presents the Pourbaix diagram of chromium in $992 \mathrm{~g} / \mathrm{L} \mathrm{LiBr}$ solution [30] with the insert of OCP $(\bullet)$ and $\mathrm{E}_{\mathrm{p}}(*)$ values. In LiBr solutions of $\mathrm{pH} 2$ and 4, both OCP and $\mathrm{E}_{\mathrm{p}}$ are in the region where $\mathrm{CrBr}^{+2}$ is stable, while at $\mathrm{pHs}$ over 4 , the stable specie is in general $\mathrm{Cr}_{2} \mathrm{O}_{3}$, so it is confirmed that it states in the passive form. According to the Pourbaix diagram and as it is shown in Figure $2 \mathrm{~b}$, at $\mathrm{pH} 12$ the repassivation of DSS is worse than the other pHs (bigger hysteresis loop and higher $i_{\text {rp }}$ value); this phenomenon is may be due to the oxidation of chromium oxide to $\mathrm{CrO}_{4}{ }^{-2}$, at potentials above the $\mathrm{E}_{\mathrm{p}}$.

The difference between $E_{p}$ and $E_{c o r r}$ is a measure of the tendency to pit nucleation [35]. The value obtained from this difference decreases with the $\mathrm{pH}$, except for $\mathrm{pH} 12$ (Figure 4a); the resistance of the material to pitting corrosion increases when this difference increases, therefore the highest resistance was found at $\mathrm{pH} 12$.

Finally the fourth region is defined at potentials higher than the $E_{p}$, where localized corrosion develops. The existence of a hysteresis loop in a cyclic potentiodynamic curve indicates that repassivation of an existing pit is possible. The larger the hysteresis loop, the more difficult repassivation is. Repassivation potential, $\mathrm{E}_{\mathrm{rp}}$, refers to the limit below which the metal remains passive, and it is defined as the 
potential where the forward and reverse scan cross; it marks the division between stable and unstable passivity [36]. Intermediate values between pitting potential and repassivation potential do not permit the formation of new pits, but allow the development of those which already existed. The narrower the hysteresis loop, defined from the data $E_{p}-E_{r p}$ in the cyclic polarization curves, the easier it becomes to repassivate the pit. Hysteresis loops do not follow any trend with $\mathrm{pH}$; at $\mathrm{pH} 12$ the highest hysteresis loop is observed and the $\mathrm{E}_{\mathrm{p}}-\mathrm{E}_{\mathrm{rp}}$ difference lay around $250 \mathrm{mV}$ (Figure 4b). Figure $4 \mathrm{~b}$ represents the repassivation ability of DSS depending on the $\mathrm{pH}$. Therefore when the $\mathrm{pH}$ is below 4 and over 10 this ability decreases, although all of them present low capacity for repassivation due to the high values $E_{p}-E_{r p}$.

Repassivation current density is the maximum current density value reached in the cyclic curve; it is an inverse measurement of the material capacity to repassivate and of the corrosion propagation. The repassivation current density is very similar in all tests, around $10 \mathrm{~mA} / \mathrm{cm}^{2}$; only at $\mathrm{pH} 12$ the $\mathrm{i}_{\text {rp }}$ presents the highest value $\left(15 \mathrm{~mA} / \mathrm{cm}^{2}\right)$. From the repassivation characteristics of DSS in $\mathrm{LiBr}$ media, when $\mathrm{pH}$ increases above 10 , this ability decreases.

\subsection{Potentiostatic experiments}

From the potentiostatic experiments at $-0.2 \mathrm{~V}_{\mathrm{Ag} / \mathrm{AgCl}}$, the passivation current density at the steady state $\left(i_{\text {pss }}\right)$ has been determined (Table 2$)$.

Figure 5 presents an example of the evolution of current density versus time during the potentiostatic tests in $\mathrm{LiBr}$ solutions at $\mathrm{pH} 4$ and 8. The current densities in all the tests exponentially decrease with time after an abrupt increase and subsequently achieve a steady state $\left(\mathrm{i}_{\mathrm{pss}}\right)$. The experiments carry out at $\mathrm{pH} 4$ and $\mathrm{pH} 2$ present current oscillations and they are very similar; furthermore in the $\mathrm{pH} 2$ solution, the current 
density becomes negative, probably due to the fact that a mass-transport limit reduction reaction overlays the anodic passivation current density. The other potentiostatic tests present a smoother shape that indicates that a stable passive film is formed on the surface with no breakdown occurring during the entire measurement period.

For acidic $\mathrm{pHs}$, the passive current density $\left(\mathrm{i}_{\mathrm{pss}}\right)$ increases with $\mathrm{pH}$; on the contrary, for basic pHs, from 8 to 12 , the passive current density presents a slightly decrease. This indicates that the behavior of the passive film is slightly dependent on the $\mathrm{pH}$ of the LiBr solutions. The insert of Figure 5 presents the full logarithmic scale of the potentiostatic tests of Figure 5. It is observed that the logarithmic current density decreases linearly with the logarithmic time in all cases; the slope represents the growth-rate of the film [16] and it grows according to the expression (2) as:

$$
\mathrm{i}=\mathrm{At}^{-\mathrm{n}}
$$

where $\mathrm{i}$ is the current used in the formation of the oxide film and $\mathrm{A}$ is the constant, $\mathrm{t}$ is the time and $\mathrm{n}$ is the slope. It is observed that the $\mathrm{pH}$ do not modify the growth rate of the passive film and in all the solutions the slope $\mathrm{n}$ is around 0.72 .

\subsection{Electrochemical impedance spectra}

To complete the characterization of the DSS / electrolyte interface, EIS measurements are made in a wide frequency range. Impedance spectra are normally displayed either in the form of a Nyquist diagram, where the opposite of the imaginary part of impedance is plotted against the real part, or of a Bode plot in which both the modulus of the impedance and the phase angle are plotted as a function of frequency. EIS measurements are made at two passive potentials, OCP and $-0.2 \mathrm{~V}_{\mathrm{Ag} / \mathrm{AgCl}}$. Figure 6 shows examples of the Nyquist and Bode plots for the DSS sample in LiBr solutions at $-0.2 \mathrm{~V}_{\mathrm{Ag} / \mathrm{AgCl} \text {. }}$ 
According to Figure 6, two regions corresponding to two time constants can be distinguished, therefore experimental impedance data is fitted to the equivalent electrical circuit (EEC) of Figure 7. It consists of the following elements; $R_{s}$ is the solution resistance, $\mathrm{R}_{\mathrm{ct}}$, is the charge transfer resistance and $\mathrm{CPE}_{\mathrm{dl}}$ is the capacitance of the multilayer corrosion products including the defects resulting from the formation of ionically conducting paths across the corrosion product, $\mathrm{CPE}_{\text {film }}$ is the capacitance of the passive layer within the pit [37] and $\mathrm{R}_{\text {film }}$ is the resistance of the passive film. The sum of $R_{c t}$ and $R_{\text {film }}$ is defined as the polarization resistance, $R_{p}$, and it is related to the corrosion resistance of the metal. Because DSS alloy is spontaneously passive, this equivalent circuit is the most suitable to describe the corrosion mechanism produced in the interface electrolyte / passive film / metal.

This model assumes that the passive film does not totally recover the metal and cannot be considered as a homogeneous layer but rather as a defective layer. In fact, neither real surfaces of solids in the active range nor passive films on metallic substrates can be considered to be ideally homogeneous.

Therefore, the high frequency capacitive semicircle can be attributed to a charge transfer process, and the neighboring second semicircle to the passive film $[38,39]$. The second time constant is connected with an additional relaxation process, whose proceeding is outlined in the presence of ion by adsorbed molecules.

According to the model of Figure 7, the electrical parameters at OCP and at -0.2 $\mathrm{V}_{\mathrm{Ag} / \mathrm{AgCl}}$ are summarized in Table 3.

At both potentials, the highest oxide film resistance $\left(R_{\text {film }}\right)$ is obtained in the LiBr $\mathrm{pH} 6$ solution, and the lowest $\mathrm{R}_{\text {film }}$ is obtained in the $\mathrm{pH} 2$ solution. The differences in $\mathrm{R}_{\text {film }}$ at $\mathrm{OCP}$ in the different $\mathrm{LiBr}$ solutions, are due to the fact that small surface modifications in the OCP values change the properties of the DSS interface in 
$992 \mathrm{~g} / \mathrm{LiBr}$ solutions. So that, authors decided to select an applied constant potential of $-0.2 \mathrm{~V}_{\mathrm{Ag} / \mathrm{AgCl}}$ to observe the electrochemical behavior of the alloy in those $\mathrm{LiBr}$ solutions. CPE values are high compared to the double-layer capacitance expected for a metal-solution interface. This indicates that some kind of adsorption phenomena is involved and contributes to the overall impedance. The depression of the double layer capacitance semicircle grows as well. If $\mathrm{n}_{\mathrm{dl}}$ is accepted to be a measure of surface inhomogeneity [40], then $\mathrm{n}_{\mathrm{dl}}$ decrease should be related to certain increase in heterogeneity resulting from surface metal roughening.

There are no differences in the $\mathrm{n}_{\mathrm{dl}}$ values, but $\mathrm{n}_{\text {film }}$ is smaller than $\mathrm{n}_{\mathrm{dl}}$, which is related to diffusion mechanisms through the passive film in DSS in a $\mathrm{LiBr}$ medium. At both potentials, OCP and $-0.2 \mathrm{~V}_{\mathrm{Ag} / \mathrm{AgCl}}, \mathrm{n}_{\mathrm{film}}$ is around 0.5 , that is, the formation of the passive film occurs through a dissolution-precipitation mechanism [41].

It may be concluded that the behavior of the DSS interface, due to the formation of a porous passive oxide layer, has $\mathrm{CPE}$ with $\mathrm{n}<1$ and with a maximum phase angle of $-75^{\circ}$ for $\mathrm{pH} 2$.

With respect to the influence of the applied potential on the electrochemical properties of the $\mathrm{DSS} / \mathrm{LiBr}$ interface, Figure 8 presents, as an example, a comparison between the data obtained in $\mathrm{pH} 4$ at the $\mathrm{OCP}$ and at $-0.2 \mathrm{~V}_{\mathrm{Ag} / \mathrm{AgCl}}$. There are no great differences in the properties of the interface as it can be observed from the results of Table 3 at OCP and at $-0.2 \mathrm{~V}_{\mathrm{Ag} / \mathrm{AgCl}}$. Only in those cases where the OCP measurements previous to EIS tests lie above $-0.2 \mathrm{~V}_{\mathrm{Ag} / \mathrm{AgCl}}$ (i.e. $\mathrm{pH} 8$ ), the $\mathrm{R}_{\text {film }}$ values are lower and the $\mathrm{CPE}_{\text {film }}$ values are higher, which can be related to the thinning of the passive film. 


\section{Conclusions}

The electrochemical behavior of DSS in different $\mathrm{LiBr}$ solutions is presented in this study. Enhanced DSS passivity in LiBr is obtained for slightly basic and acid $\mathrm{pH}$. Decreasing the $\mathrm{pH}$ may lead to localised corrosion.

The evolution of the open circuit potential at the beginning of the tests is independent of $\mathrm{pH}$, it increases with time in all cases.

From the results of the polarization curves, it is clear that DSS in $\mathrm{LiBr}$ at $\mathrm{pH} 12$ presents better resistance to general and pitting corrosion; by contrast it presents worse repassivation ability than at the other $\mathrm{pH}$ values.

The polarization curves and EIS tests allow us to conclude that in $\mathrm{LiBr}$ media, the most suitable corrosion mechanism includes the double layer and the formation of a passive film on the alloy surface. The resistance of the passive film is higher in $\mathrm{LiBr}$ solutions with $\mathrm{pH}$ between 6 and 8 .

The results present here give a better understanding of the corrosion resistance of DSS under very aggressive conditions. There are no great differences in the results of the characterization of the passive film of DSS at OCP, which is in the passive range, and at the applied passive potential. Indeed, under the studied conditions in this work, it is better to do EIS measurements under the applied potential than at OCP owing to the fact that the dispersion in the OCP measurement could also influence the results of the interface characterization.

Acknowledgements: We wish to express our gratitude to MCYT (CTQ2009-07518), to Feder and to Dr. M. Asunción Jaime for her translation assistance. 


\section{References}

[1] J. W. Furlong, The Air Pollution Consultant, Elsevier Science Inc. Elsevier Science Inc. 1994.

[2] A. D. Althaus, C. H. Turnquist, Modern Refrigeration Air and Air Conditioning. Goodheart-Wilcox. 2004.

[3] D. Itzhak, T. Greenberg, Galvanic corrosion of a copper alloy in lithium bromide heavy brine environments, Corrosion. 55 (1999) 795-799.

[4] A. Igual-Muñoz, J. García-Antón, J.L. Guiñón, V. Pérez-Herranz, Effects of solution temperature on localized corrosion of high nickel content stainless steels and nickel in chromated LiBr solution, Corrosion Sci. 48 (2006) 3349-3374.

[5] A. Igual-Muñoz, J. García-Antón, J.L. Guiñón, V. Pérez-Herranz, Inhibition effect of chromate on the passivation and pitting corrosion of a duplex stainless steel in $\mathrm{LiBr}$ solutions using electrochemical techniques, Corrosion Sci. 49 (2007) 3200-3225.

[6] S. Zhou, M.M. Stack, R.C. Newman, Characterization of synergistic effects between erosion and corrosion in an aqueous environment using electrochemical techniques, Corrosion. 52 (1996) 934-946.

[7] G.T. Burstein, P.C. Pistorius, S.P. Mattin, The Nucleation and Growth of Corrosion Pits on Stainless-Steel, Corrosion Sci. 35 (1993) 57-62.

[8] P.C. Pistorius, G.T. Burstein, Metastable Pitting Corrosion of Stainless-Steel and the Transition to Stability, Phil Trans Roy Soc London A341 (1992) 531-559.

[9] V. Muthupandi, P. Bala Srinivasan, S.K. Seshadri, S. Sundaresan, Effect of weld metal chemistry and heat input on the structure and properties of duplex stainless steel welds, Mater. Sci. Eng. A-Struct. Mater. Prop. Microstruct. Process. 358 (2003) 9-16.

[10] S.A. Tavara, M.D. Chapetti, J.L. Otegui, C. Manfredi, Influence of nickel on the susceptibility to corrosion fatigue of duplex stainless steel welds, Int. J. Fatigue. 23 (2001) 619-626.

[11] Y.H. Yau, M.A. Streicher, Galvanic Corrosion of Duplex FeCr-10-Percent NiAlloys in Reducing Acids, Corrosion. 43 (1987) 366-377.

[12] E. Symniotis, Galvanic effects on the active dissolution of duplex stainless steels, Corrosion. 46 (1990) 2-12.

[13] A. Laitinen, H. Hanninen, Chloride-induced stress corrosion cracking of powder metallurgy duplex stainless steels, Corrosion. 52 (1996) 295-306.

[14] N. Sridhar, J. Kolts, Effects of Nitrogen on the Selective Dissolution of A Duplex Stainless-Steel, Corrosion. 43 (1987) 646-651.

[15] R.Leiva-García, J.García-Antón, M.J.Muñoz-Portero, Contribution to the elucidation of corrosion initiation through confocal laser scanning microscopy (CLSM), Corrosion Sci. 52 (2010) 2133-2142. 
[16] J.D. Kim, S.I. Pyun, Effects of electrolyte composition and applied potential on the repassivation kinetics of pure aluminium, Electrochim. Acta. 40 (1995) 1863-1869.

[17] C.T. Liu, J.K. Wu, Influence of $\mathrm{pH}$ on the passivation behavior of 254SMO stainless steel in 3.5\% NaCl solution, Corrosion Sci. 49 (2007) 2198-2209.

[18] I. Epelboin, M. Keddam, O.R. Mattos, H. Takenouti, The dissolution and passivation of $\mathrm{Fe}$ and $\mathrm{Fe}-\mathrm{Cr}$ alloys in acidified sulphate medium: Influences of $\mathrm{pH}$ and Cr content, Corrosion Sci. 19 (1979) 1105-1112.

[19] M.J. Carmezim, A.M. Simoes, M.F. Montemor, M.Da Cunha Belo, Capacitance behavior of passive films on ferritic and austenitic stainless steel, Corrosion Sci. 47 (2005) 581-591.

[20] A.Igual-Muñoz, J.García-Antón, J.L.Guiñón, V.Perez-Herranz, Comparison of inorganic inhibitors of copper, nickel and copper-nickels in aqueous lithium bromide solution, Corrosion Sci. 50 (15-12-2004) 957-966.

[21] D.M.García-García, J.García-Antón, A.Igual-Muñoz, E.Blasco-Tamarit, Effect of cavitation on the corrosion behaviour of welded and non-welded duplex stainless steel in aqueous LiBr solutions, Corrosion Sci. 48 (2006) 2380-2405.

[22] ASTM G-5. Test Method for Making Potentiostatic and Potentiodynamic Anodic Polarization Measurements, ASTM International, 1994.

[23] ASTM G-61. Standard Test Method for Conducting Cyclic Potentiodynamic Polarization Measurements for Localized Corrosion Susceptibility of Iron-, Nickel-, or Cobalt-Based Alloys, ASTM International, 1994.

[24] E. McCafferty, Validation of corrosion rates measured by the Tafel extrapolation method, Corrosion Sci. 47 (2005) 3202-3215.

[25] M.A. Amin, S.S.A. El Rehim, H.T.M. Abdel-Fatah, Electrochemical frequency modulation and inductively coupled plasma atomic emission spectroscopy methods for monitoring corrosion rates and inhibition of low alloy steel corrosion in $\mathrm{HCl}$ solutions and a test for validity of the Tafel extrapolation method, Corrosion Sci. 51 (2009) 882894.

[26] M.A. Amin, K.F. Khaled, S.A. Fadl-Allah, Testing validity of the Tafel extrapolation method for monitoring corrosion of cold rolled steel in $\mathrm{HCl}$ solutions Experimental and theoretical studies, Corrosion Sci. 52 (2010) 140-151.

[27] E. Bardal, Corrosion and Protection, Engineering Materials And Processes, Springer, USA, 2004.

[28] R.G. Kelly, J.R. Scully, D.W. Shoesmith, R.G. Buchheit, Electrochemical Techniques in Corrosion Science and Engineering, Marcel Dekker, New York, 2003.

[29] J. A. Sedriks, Corrosion of Stainless Steels, John Wiley \& Sons, 1979. 
[30] M. J. Muñoz-Portero, J. García-Antón, J. L. Guiñón, V. Pérez-Herranz, Pourbaix diagrams for chromium in concentrated aqueous lithium bromide solutions at $25^{\circ} \mathrm{C}$, Corrosion Sci. 51 (2009) 807-819.

[31] D. Landolt, Corrosion and surface chemistry of metals, EPFL Press (2003).

[32] L. Freire, M.J. Carmezim, M.G.S. Ferreira, M.F. Montemor, The passive behaviour of AISI 316 in alkaline media and the effect of $\mathrm{pH}$ : A combined electrochemical and analytical study, Electrochim. Acta. In Press, Corrected Proof (2009)

[33] R. Ovarfort, Critical pitting temperature measurements of stainless steels with an improved electrochemical method, Corrosion Sci. 29 (1989) 987-993.

[34] K.V.S. Ramana, T. Anita, S. Mandal, S. Kaliappan, H. Shaikh, P.V. Sivaprasad, R.K. Dayal, H.S. Khatak, Effect of different environmental parameters on pitting behavior of AISI type 316L stainless steel: Experimental studies and neural network modeling, Mater. Des. 30 (2009) 3770-3775.

[35] M. Kaneko, H.S. Isaacs, Pitting of stainless steel in bromide, chloride and bromide/chloride solutions, Corrosion Sci. 42 (2000) 67-78.

[36] T. Belleze, G. Roventi, R. Fratesi, Electrochemical characterization of three corrosion-resistant alloys after processing for heating-element sheathing, Electrochim. Acta 49 (2004) 3005-3014.

[37] J.H. Lee, S.H. Ahn, J.G. Kim, Effect of Al additions in WC-(Cr1-xAlx)N coatings on the corrosion resistance of coated AISI D2 steel in a deaerated 3.5 wt. $\% \mathrm{NaCl}$ solution, Surf. Coat. Technol. 190 (2005) 417-425.

[38] A. Bautista, G. Blanco, F. Velasco, A. Gutierrez, L. Soriano, F.J. Palomares, H. Takenouti, Changes in the passive layer of corrugated austenitic stainless steel of low nickel content due to exposure to simulated pore solutions, Corrosion Sci. 51 (2009) 785-792.

[39] Y.X. Qiao, Y.G. Zheng, W. Ke, P.C. Okafor, Electrochemical behaviour of high nitrogen stainless steel in acidic solutions, Corrosion Sci. 51 (2009) 979-986.

[40] A. Popova, E. Sokolova, S. Raicheva, M. Christov, AC and DC study of the temperature effect on mild steel corrosion in acid media in the presence of benzimidazole derivatives, Corrosion Sci. 45 (2003) 33-58.

[41] K.M. Ismail, S.S. El Egamy, M. Abdelfatah, Effects of $\mathrm{Zn}$ and $\mathrm{Pb}$ as alloying elements on the electrochemical behaviour of brass in borate solutions, J. Appl. Electrochem. 31 (2001) 663-670. 
Figure 1. Open circuit potential evolution of DSS in 992 g / L LiBr solutions.

Figure 2. Cyclic potentiodynamic curves of duplex stainless steel in $992 \mathrm{~g} / \mathrm{L} \mathrm{LiBr}$ at acid (a) and basic pHs (b).

Figure 3. Pourbaix diagram of chromium in $992 \mathrm{~g} / \mathrm{L} \mathrm{LiBr}$ solution with OCP $(\bullet)$ and $\mathrm{E}_{\mathrm{p}}(*)$ values of DSS in $992 \mathrm{~g} / \mathrm{L}$ LiBr solutions.

Figure 4. Difference of $E_{p}$ and $E_{\text {corr }}$ vs. $\mathrm{pH}$ (a) and difference of $E_{p}$ and $E_{r p}$ vs. pH (b) for duplex stainless steel in $992 \mathrm{~g} / \mathrm{L} \mathrm{LiBr}$ solutions.

Figure 5. Evolution of current density versus time for duplex stainless steel in $992 \mathrm{~g} /$ $\mathrm{L} \mathrm{LiBr}$ at $\mathrm{pH} 4$ and 8 . The insert corresponds to the full logarithmic scale.

Figure 6. Nyquist (a) and Bode (b) plots of EIS data at $-0.2 \mathrm{~V}_{\mathrm{Ag} / \mathrm{AgCl}}$ of duplex stainless steel in $992 \mathrm{~g} / \mathrm{L} \mathrm{LiBr}$ solutions.

Figure 7. Equivalent circuit for the analysis of impedance spectra. $\mathrm{R}_{\mathrm{s}}$ solution resistance, $\mathrm{R}_{\mathrm{ct}}$ charge transfer resistance, $\mathrm{CPE}_{\mathrm{dl}}$ double layer $\mathrm{CPE}, \mathrm{R}_{\text {film }}$ oxide film resistance, $\mathrm{CPE}_{\text {film }} \mathrm{CPE}$ of oxide film.

Figure 8. Comparison of the Nyquist plot at $-0.2 \mathrm{~V} \mathrm{Ag} / \mathrm{AgCl}$ and OCP for duplex stainless steel in $992 \mathrm{~g} / \mathrm{L} \mathrm{LiBr}$ solution $(\mathrm{pH}=4)$. 
Table 1. Electrochemical parameters of the duplex stainless steel in the $992 \mathrm{~g} / \mathrm{L} \mathrm{LiBr}$ solution.

\begin{tabular}{|c|c|c|c|c|c|c|c|}
\hline pH & $\begin{array}{c}\text { OCP } \\
\left(m V_{\text {Ag/AgCl }}\right) \\
\end{array}$ & $\begin{array}{c}\mathbf{E}_{\text {corr }} \\
\left(\mathrm{mV}_{\mathrm{Ag} / \mathrm{AgCl}}\right) \\
\end{array}$ & $\begin{array}{c}\mathbf{i}_{\text {corr }} \\
\left(\mu \mathrm{A} / \mathbf{c m}^{2}\right) \\
\end{array}$ & $\begin{array}{c}\mathbf{i}_{\mathrm{p}} \\
\left(\mu \mathrm{A} / \mathrm{cm}^{2}\right) \\
\end{array}$ & $\begin{array}{c}\mathbf{E}_{\mathrm{p}} \\
\left(\mathrm{m} \mathrm{V}_{\mathrm{Ag} / \mathrm{AgCl}}\right) \\
\end{array}$ & $\begin{array}{c}\mathbf{i}_{\mathbf{r p}} \\
\left(\mathrm{mA} / \mathrm{cm}^{2}\right) \\
\end{array}$ & 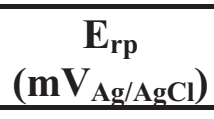 \\
\hline 2 & $-216 \pm 35$ & $-272 \pm 5$ & $1.8 \pm 0.5$ & - & $-144 \pm 1(*)$ & - & - \\
\hline 4 & $-142 \pm 45$ & $-557 \pm 42$ & $1.4 \pm 0.3$ & $8.5 \pm 2.7$ & $-20 \pm 3$ & $10.8 \pm 0.5$ & $-273 \pm 8$ \\
\hline 6 & $-178 \pm 20$ & $-580 \pm 35$ & $1.0 \pm 0.6$ & $7.5 \pm 2.6$ & $-81 \pm 10$ & $10.2 \pm 0.3$ & $-336 \pm 13$ \\
\hline 8 & $-182 \pm 45$ & $-553 \pm 50$ & $1.0 \pm 0.5$ & $7.0 \pm 3.5$ & $-85 \pm 5$ & $10.6 \pm 0.6$ & $-326 \pm 2$ \\
\hline 10 & $-182 \pm 3$ & $-498 \pm 23$ & $0.9 \pm 0.4$ & $5.9 \pm 1.5$ & $-32 \pm 10$ & $11.0 \pm 0.2$ & $-282 \pm 20$ \\
\hline 12 & $-205 \pm 14$ & $-537 \pm 92$ & $0.8 \pm 0.2$ & $5.4 \pm 2.9$ & $24 \pm 72$ & $15.2 \pm 4.3$ & $-328 \pm 58$ \\
\hline
\end{tabular}


Table 2. $\mathrm{i}_{\mathrm{pss}}$ at $-0.2 \mathrm{~V}_{\mathrm{Ag} / \mathrm{AgCl}}$ of the duplex stainless steel in the $992 \mathrm{~g} / \mathrm{L} \mathrm{LiBr}$ solutions.

\begin{tabular}{ccccccc}
\hline $\mathbf{p H}$ & $\mathbf{2}$ & $\mathbf{4}$ & $\mathbf{6}$ & $\mathbf{8}$ & $\mathbf{1 0}$ & $\mathbf{1 2}$ \\
\hline $\mathbf{i}_{\mathbf{p s s}}\left(\boldsymbol{\mu} \mathbf{A} / \mathbf{c m}^{2}\right)$ & 2.5 & 3.0 & 4.1 & 4.5 & 4.1 & 3.5 \\
\hline
\end{tabular}


Table 3. Equivalent circuit parameters in $992 \mathrm{~g} / \mathrm{L}$ LiBr solutions at OCP and -0.2 $\mathrm{V}_{\mathrm{Ag} / \mathrm{AgCl} \text {. }}$

\begin{tabular}{|c|c|c|c|c|c|c|c|}
\hline \multicolumn{8}{|c|}{$\overline{\mathrm{OCP}}$} \\
\hline pH & $\begin{array}{c}\mathbf{R}_{\mathrm{s}} \\
\left(\Omega \cdot \mathrm{cm}^{2}\right)\end{array}$ & $\begin{array}{c}R_{\mathrm{ct}} \\
\left(\mathrm{k} \Omega \cdot \mathrm{cm}^{2}\right)\end{array}$ & $\begin{array}{c}\mathrm{CPE}_{\mathrm{dl}} \\
\left(\mu \mathrm{F} / \mathrm{cm}^{2}\right)\end{array}$ & $\mathbf{n}_{\mathbf{d l}}$ & $\begin{array}{c}\mathrm{CPE}_{\text {film }} \\
\left(\mu \mathrm{F} / \mathrm{cm}^{2}\right)\end{array}$ & $\mathbf{n}_{\text {film }}$ & $\begin{array}{c}R_{\text {film }} \\
\left(\mathrm{k} \Omega \cdot \mathrm{cm}^{2}\right)\end{array}$ \\
\hline 2 & 2.1 & 0.7 & 75 & 0.88 & 220 & 0.68 & 5 \\
\hline 4 & 2.2 & 1.5 & 100 & 0.85 & 180 & 0.55 & 22 \\
\hline 6 & 1.9 & 1.4 & 167 & 0.77 & 260 & 0.57 & 150 \\
\hline 8 & 1.5 & 0.2 & 75 & 0.88 & 350 & 0.62 & 11 \\
\hline 10 & 2.1 & 1.5 & 81 & 0.87 & 143 & 0.60 & 13 \\
\hline 12 & 2.3 & 1.6 & 93 & 0.85 & 250 & 0.50 & 90 \\
\hline \multicolumn{8}{|c|}{$-0.2 V_{\mathrm{Ag} / \mathrm{AgCl}}$} \\
\hline pH & $\begin{array}{c}\mathbf{R}_{\mathrm{s}} \\
\left(\Omega \cdot \mathrm{cm}^{2}\right)\end{array}$ & $\begin{array}{c}R_{\mathrm{ct}} \\
\left(\mathrm{k} \Omega \cdot \mathrm{cm}^{2}\right)\end{array}$ & $\begin{array}{c}\mathrm{CPE}_{\mathrm{dl}} \\
\left(\mu \mathrm{F} / \mathrm{cm}^{2}\right)\end{array}$ & $\mathbf{n}_{\mathbf{d l}}$ & $\begin{array}{c}\mathrm{CPE}_{\text {film }} \\
\left(\mu \mathrm{F} / \mathrm{cm}^{2}\right)\end{array}$ & $\mathbf{n}_{\text {film }}$ & $\underset{\left(\mathrm{k} \Omega \cdot \mathrm{cm}^{2}\right)}{R_{\text {film }}}$ \\
\hline 2 & 3.8 & 2.0 & 36 & 0.90 & 280 & 0.50 & 13 \\
\hline 4 & 4.5 & 1.6 & 100 & 0.79 & 260 & 0.63 & 22 \\
\hline 6 & 4.4 & 1.6 & 41 & 0.85 & 130 & 0.44 & 82 \\
\hline 8 & 5.0 & 2.8 & 28 & 0.86 & 155 & 0.46 & 70 \\
\hline 10 & 3.0 & 4.0 & 85 & 0.83 & 250 & 0.60 & 25 \\
\hline 12 & 4.5 & 1.7 & 38 & 0.87 & 130 & 0.50 & 21 \\
\hline
\end{tabular}




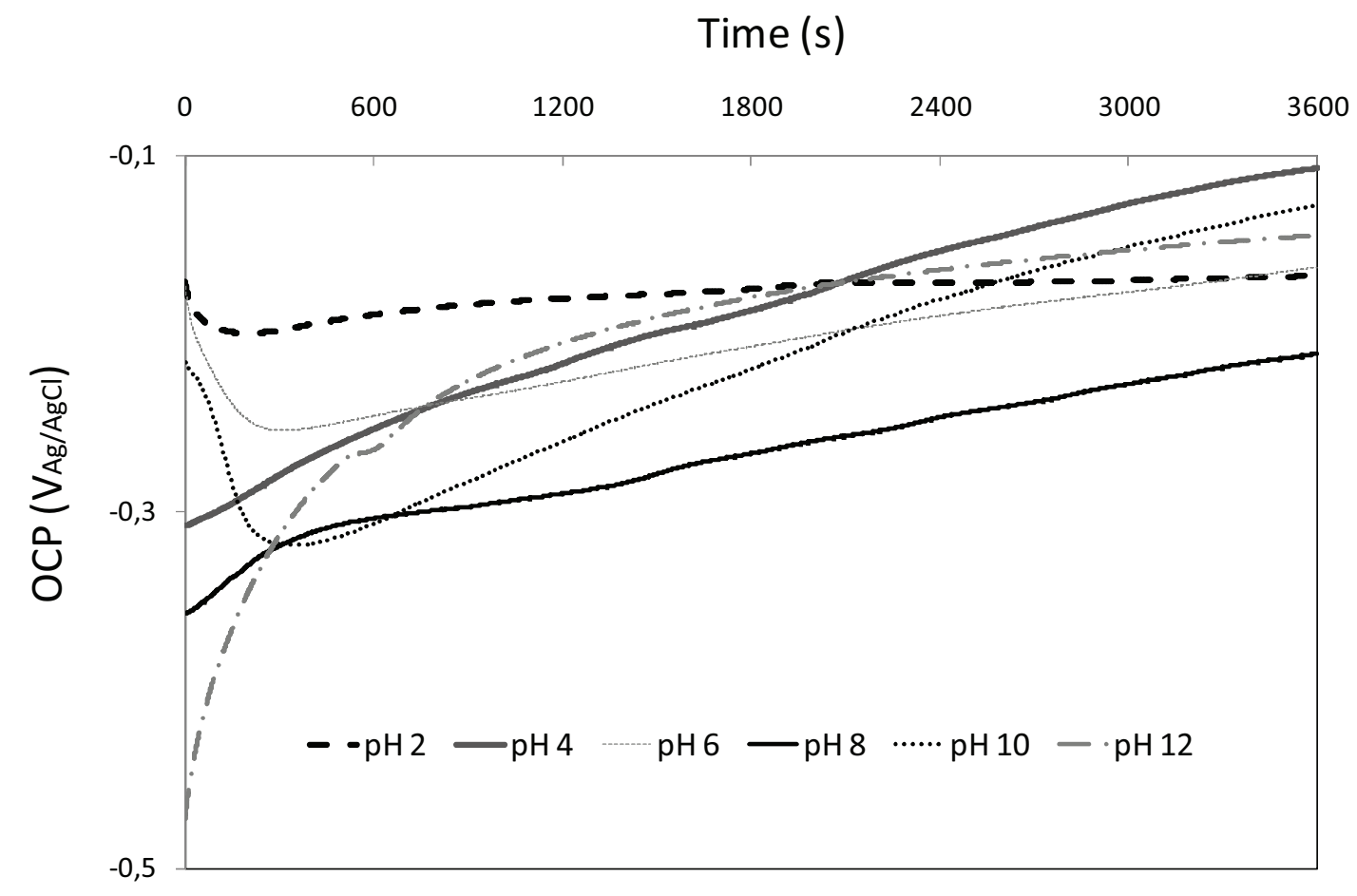


a)

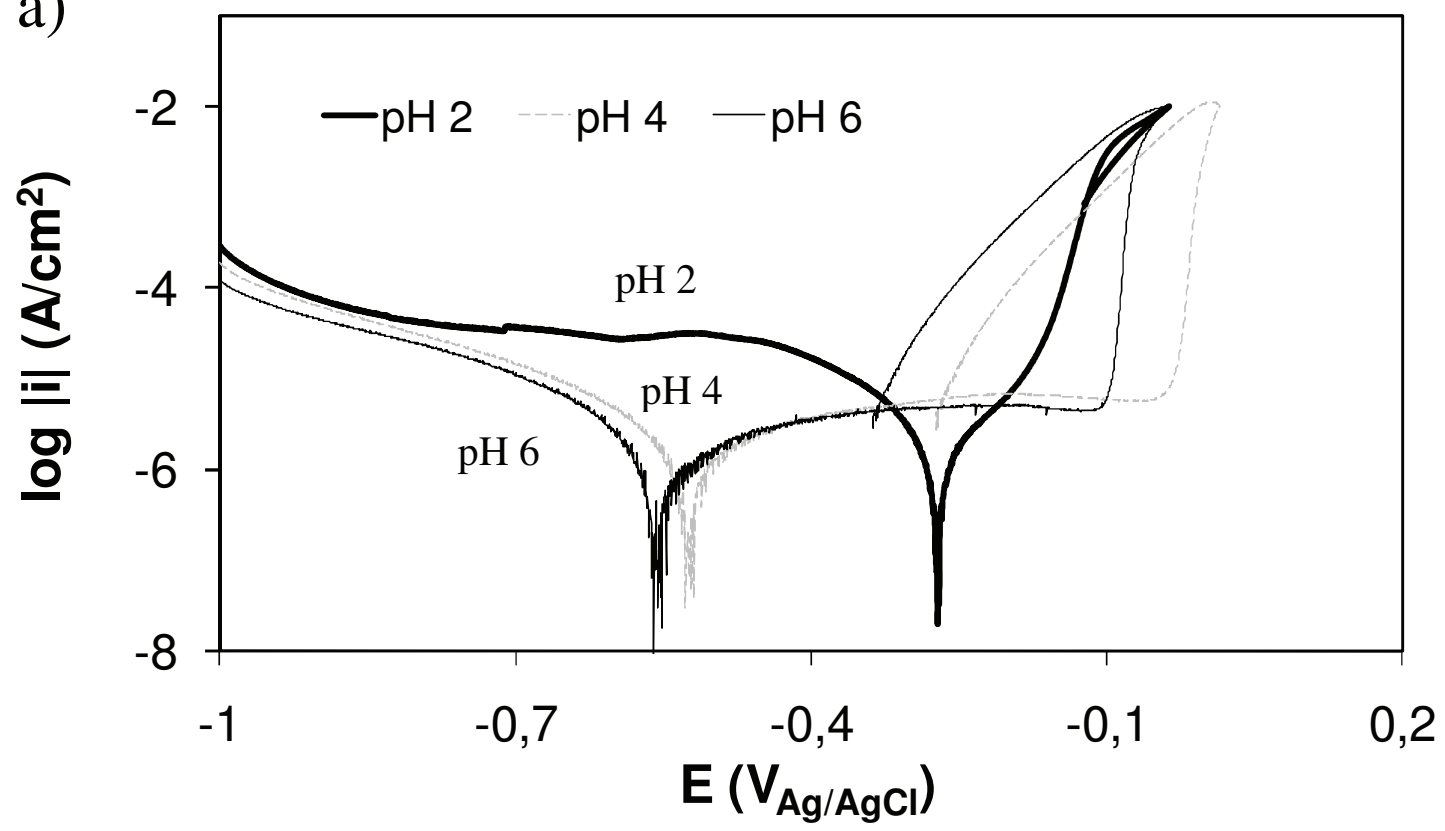

b)

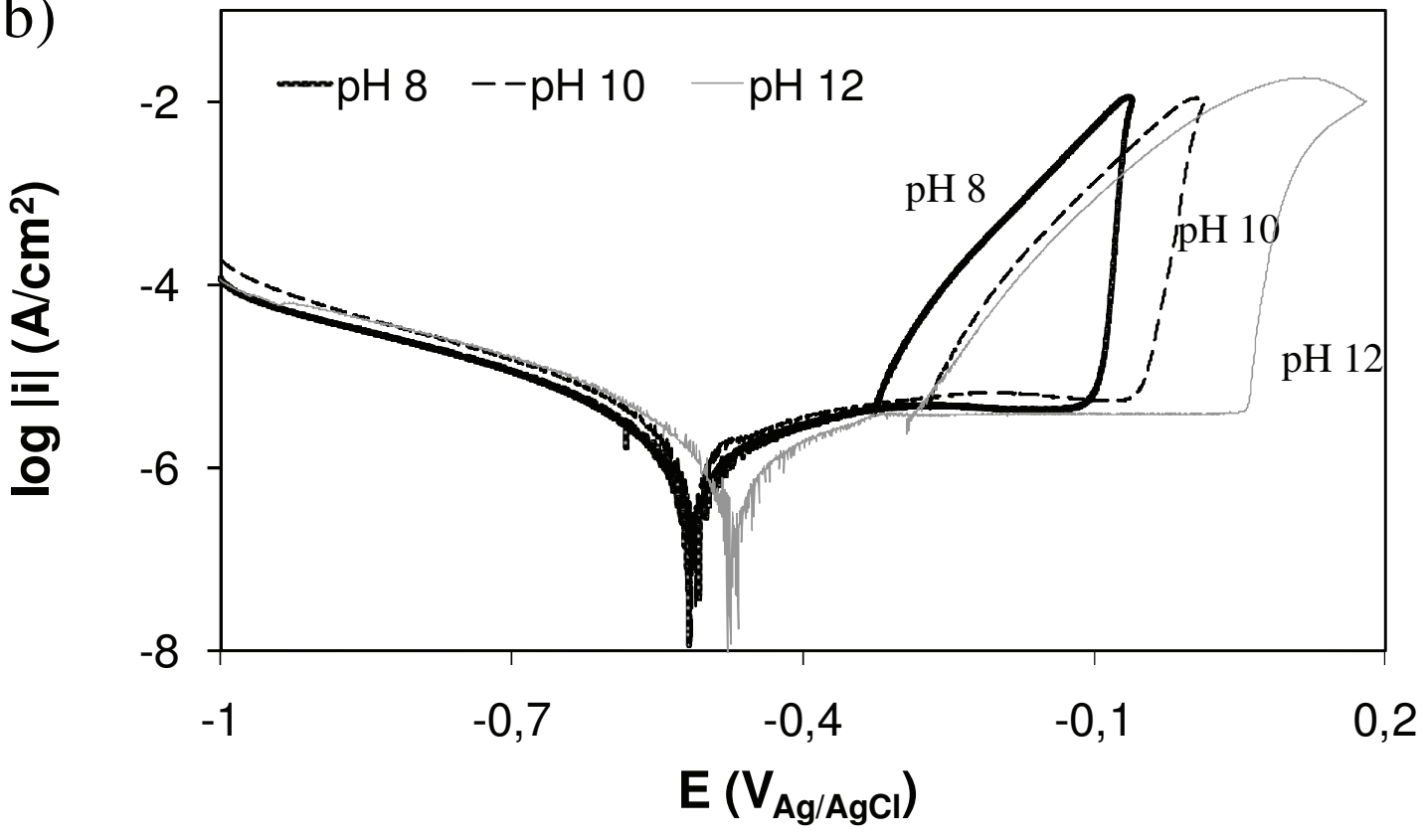




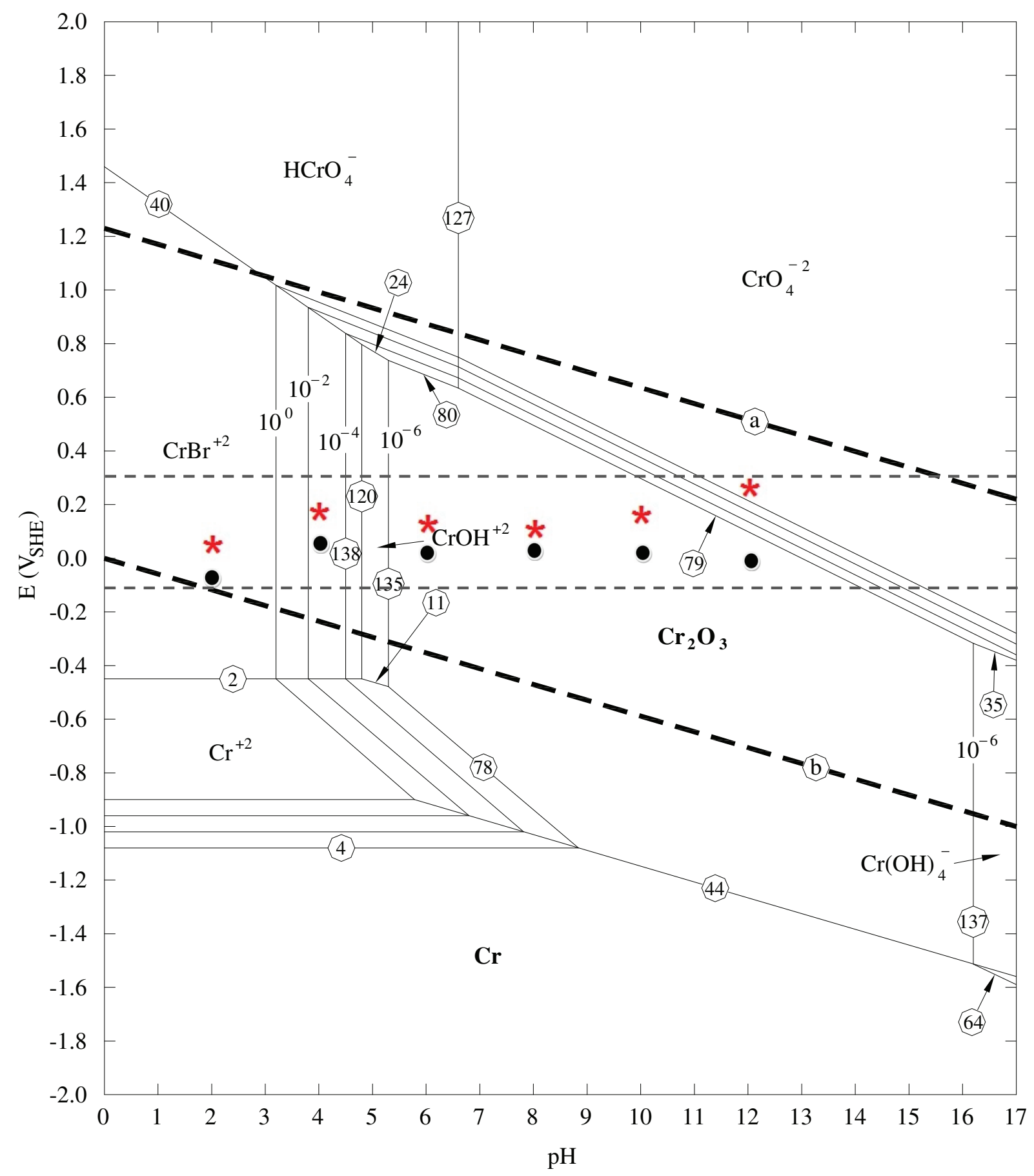


Figure 4
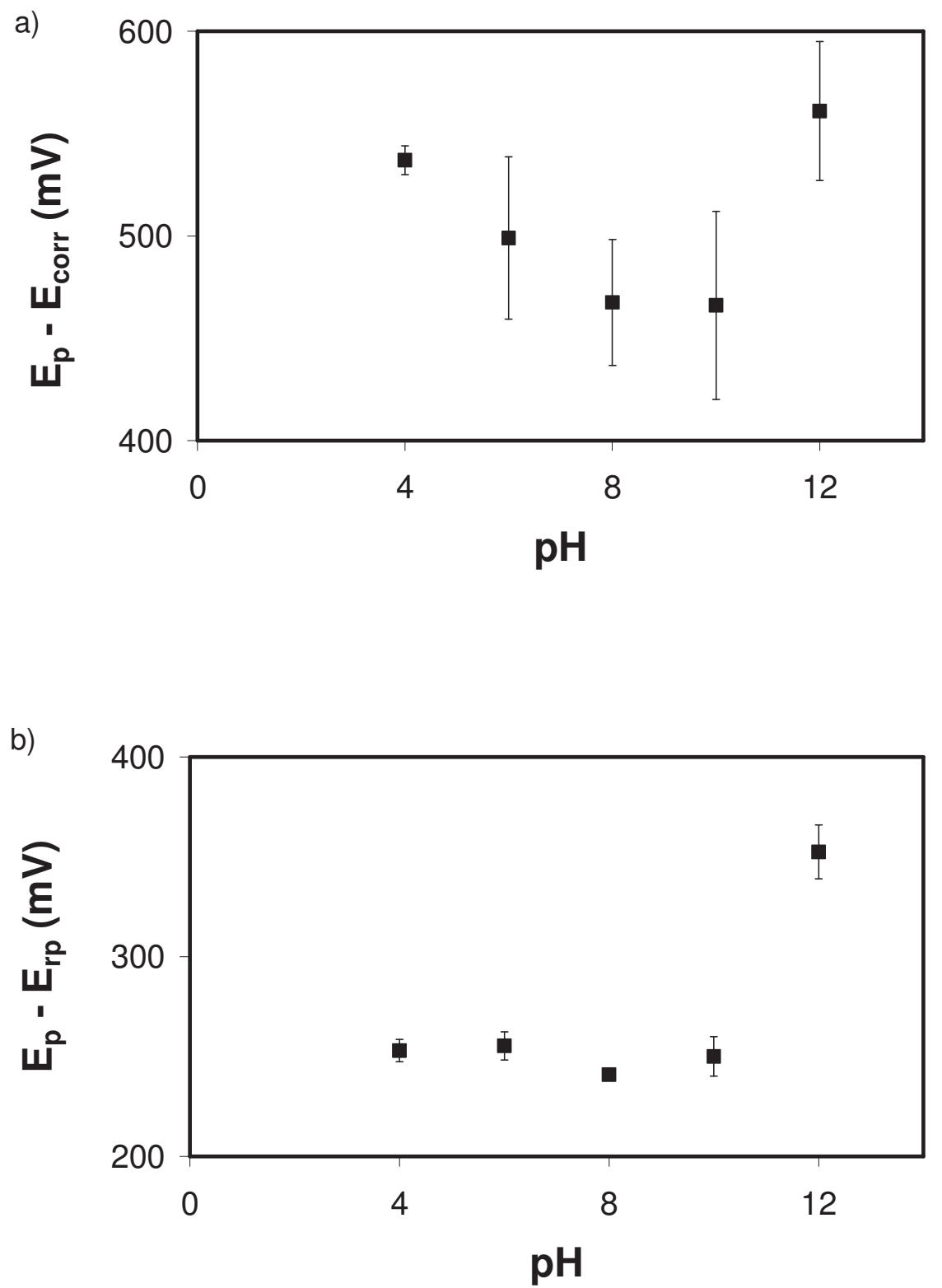
Figure 5

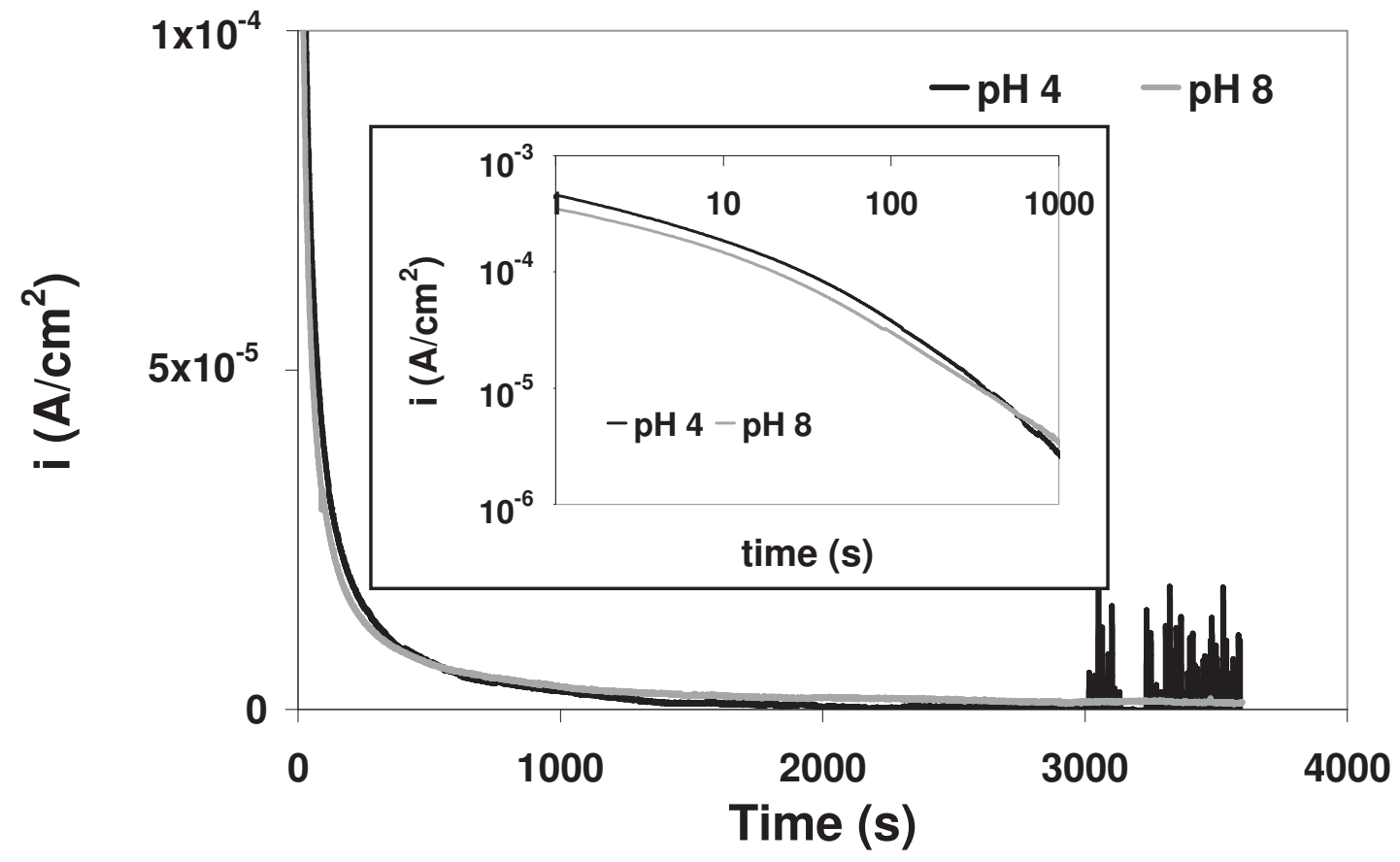



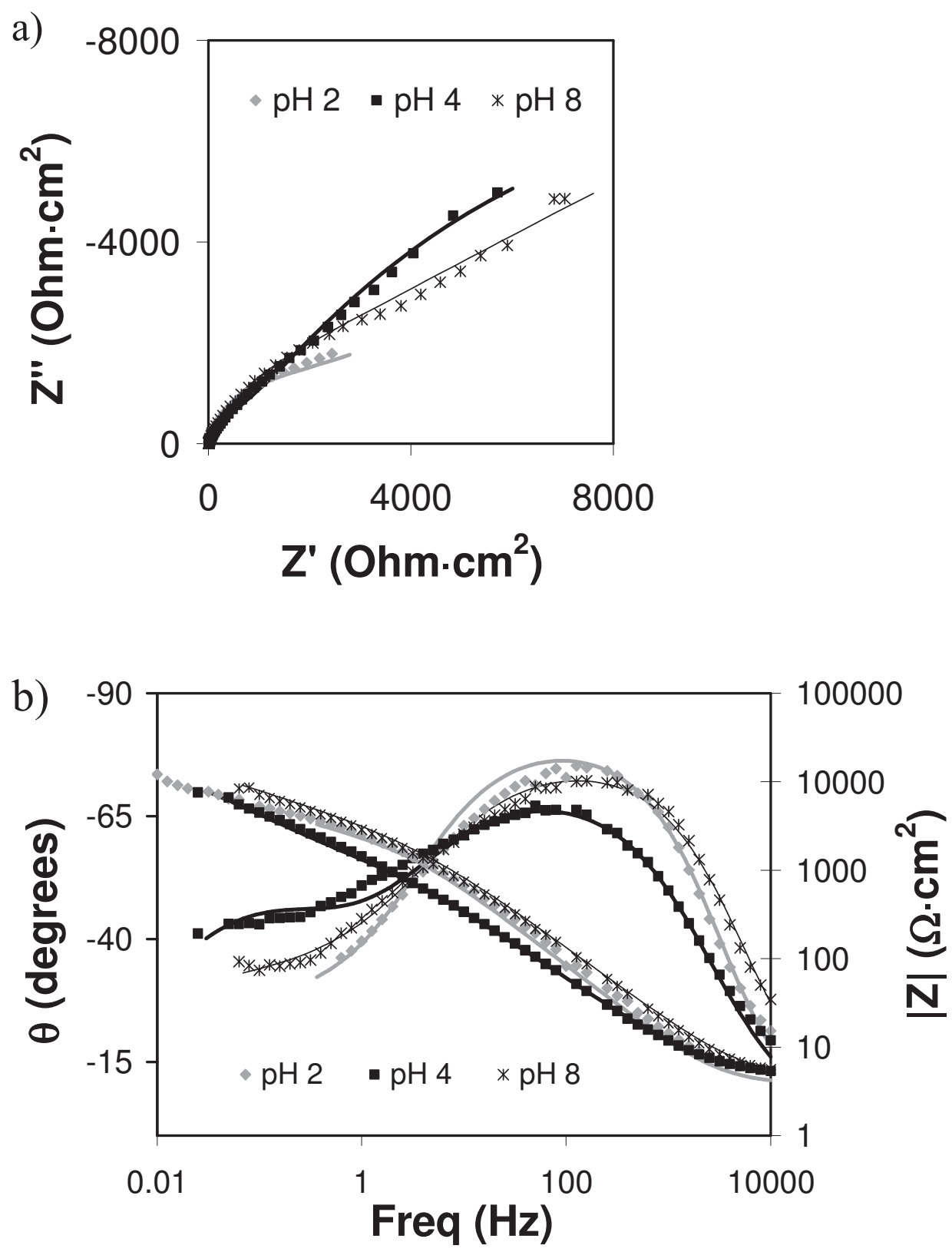


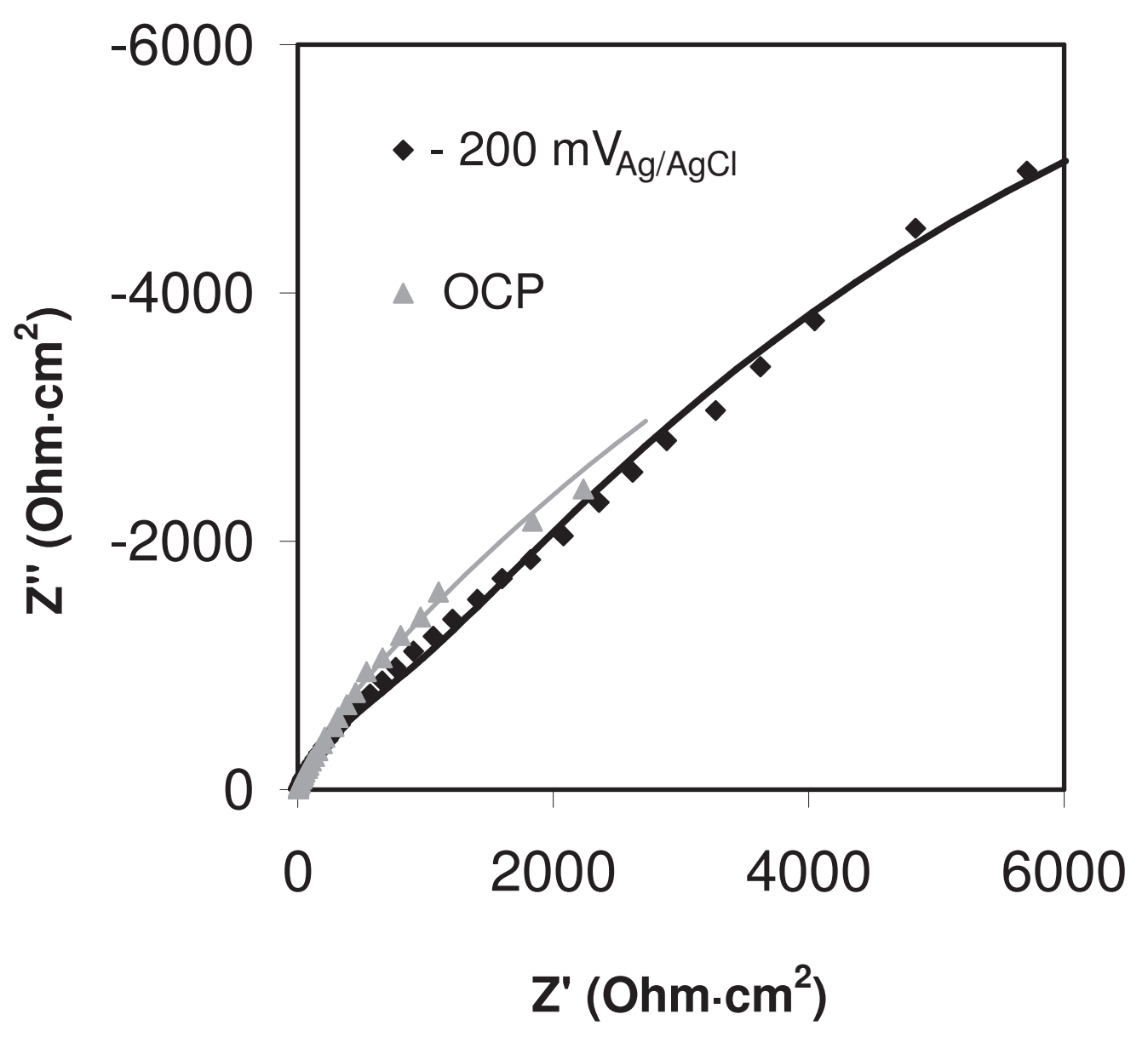

Figure 8

$\mathrm{Z}^{\prime}\left(\mathrm{Ohm} \cdot \mathrm{cm}{ }^{2}\right)$ 